\title{
Within-population spatial synchrony in mast seeding of North American oaks
}

\author{
Andrew Liebhold, Victoria Sork, Mikko Peltonen, Walter Koenig, Ottar N. Bjørnstad, Robert Westfall, \\ Joseph Elkinton and Johannes M. H. Knops
}

\begin{abstract}
Liebhold, A., Sork, V., Peltonen, M., Koenig, W., Bjørnstad, O. N., Westfall, R., Elkinton, J. and Knops, J. M. H. 2004. Within-population spatial synchrony in mast
\end{abstract} seeding of North American oaks. - Oikos 104: 156-164.

\begin{abstract}
Mast seeding, the synchronous production of large crops of seeds, has been frequently documented in oak species. In this study we used several North American oak data-sets to quantify within-stand $(<10 \mathrm{~km})$ synchrony in mast dynamics. Results indicated that intraspecific synchrony in seed production always exceeded interspecific synchrony and was essentially constant over distances ranging from 100 $\mathrm{m}$ to $10 \mathrm{~km}$. Asynchrony between species was at least partially attributable to differences in the endogenous dynamics in seed production caused by the varying numbers of years ( 1 or 2$)$ required to mature seeds. Similarly, the magnitude of intraspecific seed production synchrony was related to intraspecific variation in endogenous dynamics; this intraspecific variation could be caused by spatial variation in habitat conditions. These results indicate that both interspecific and intraspecific variation in the endogenous processes generating variability in seed production may influence the magnitude of spatial synchrony in total (all species) mast production. Such findings may be of significance to understanding interactions between synchrony in mast seeding and animal consumer populations.
\end{abstract}

\begin{abstract}
A. Liebhold, USDA Forest Service, 180 Canfield St., Morgantown, WV 26505, USA (aliebhold@fs.fed.us). - V. Sork, Dept of Organismic Biology, Ecology, and Evolution; and Inst. of the Environment, Univ. of California Los Angeles, Los Angeles, CA 90095-1786, USA. - M. Peltonen, Ministry of Agriculture and Forestry, P.O. Box 30, FIN-00023 Governement, Helsinki, Finland. - W. Koenig, Hastings Natural History Reservation, Univ. of California, Berkeley, Carmel Valley, CA 93924, USA - - O. N. Bjornstad, Depts of Entomology and Biology, Penn State Univ., University Park, PA 16802, USA. - R. Westfall, USDA Forest Service Sierra Nevada Research Center, Berkeley, CA 94701, USA. - J. Elkinton, Dept of Entomology. Univ. of Massachusetts, Amherst, MA 01003, USA. - J. M. H. Knops, School of Biological Sciences, Univ. of Nebraska - Lincoln, Lincoln, NE 68588-0118, USA.
\end{abstract}

Mast seeding is the synchronous production of large numbers of seeds within a population of plants (Janzen 1969, Silverton 1980, Sork et al. 1993, Kelly 1994, Kelly and Sork 2002). Masting has been documented in a wide variety of groups but appears to be particularly common among temperate tree species. From a statistical perspective, mast seeding has at least three important components that may be used to describe the phenomenon in any plant population: temporal variability (typically measured as the among-yr coefficient of variation in seed production by the population, $\mathrm{CV}_{\mathrm{p}}$ ), synchrony in annual mast production among individuals within a population, and spatial synchrony among populations (Herrera 1998, Herrera et al. 1998, Buonaccorsi et al. 2003, Koenig et al. 2003).

The ecological significance of mast seeding may be manifold. There is considerable evidence that fluctuations in seed production may satiate seed predators and thereby allow a proportion of individuals to "escape" predation, which would likely affect temporal patterns

Accepted 7 June 2003

Copyright (C) OIKOS 2004

ISSN 0030-1299 
of plant recruitment (Sork et al. 1983, Sork 1993). In many cases, plant seeds play critical roles in food webs and temporal pulses in their numbers may have cascading effects on higher trophic levels (Liebhold et al. 2000, Ostfeld and Keesing 2000, Selås et al. 2001). Population densities of seed consumers may temporally track fluctuations in mast abundance and geographically synchronous pulses in mast availability may cause geographically similar patterns of spatial synchrony in consumers (Koenig and Knops 2001).

Spatial synchrony of masting among plant populations has been extensively studied. Work by Koenig et al. (1994b, 1999) and Koenig and Knops (1998) indicates that intraspecific mast synchrony in temperate tree populations may be high and extend to as far as $1000 \mathrm{~km}$; there is evidence that this synchrony in masting may cause similar geographical patterns of synchrony in seed consumer populations (Liebhold et al 2000, Ostfeld and Keesing 2000, Koenig and Haydock 2001). In contrast to previous studies of synchrony among populations, we focus here on synchrony within a population using several North American oaks (genus Quercus) as case studies. We investigated how synchrony varies as a function of relatively short distance $<10 \mathrm{~km}$, comparing patterns within and among species. Our aim was to measure mast synchrony at the spatial scale at which many seed consumer populations operate. In addition, we quantified spatial synchrony in total (community-wide, all species) mast production because variation in total seed production is likely to have the greatest influence on seed eaters.

\section{Methods}

\section{Data-sets}

We used data consisting of yearly counts of acorns at three areas in central coastal California, one in the Ozark Mountain region of Missouri and one in western Massachusetts (Table 1). Data from the three California areas consisted of yearly visual counts of acorns on individual trees (Koenig et al. 1994a); a detailed description of data collection methods is available elsewhere (Koenig et al. 1994b). At the Missouri and Massachusetts study areas, data were collected in a series of plots at which acorns were annually sampled in traps placed below the forest canopy. In contrast to the California data, counts of acorns in these traps may have originated from several different trees. Counts from trap data were averaged over several traps to form an estimated mean for each plot (Table 1). Data at the Missouri site were collected as part of a study of the effects of forest thinning on acorn yield, and Massachusetts data were collected in a study of gypsy moth/small mammal/acorn interactions; full descriptions of data collection methods are provided elsewhere (Elkinton et al. 1996, Sullivan 2001). Because counts from the California sites corresponded with individual trees while the Missouri and Massachusetts data consisted of average counts sampled over many trees, it was not possible to directly compare levels of variability or synchrony among these different areas. Instead analyses focused on comparisons of variability and synchrony within each area.

Table 1. Characteristics of the five study site locations.

\begin{tabular}{|c|c|c|c|c|c|}
\hline Study area & $\begin{array}{l}\text { Approximate } \\
\text { geographical } \\
\text { dimensions }\end{array}$ & Species & Sampling unit & $\begin{array}{l}\text { Number of } \\
\text { samples }\end{array}$ & Years \\
\hline $\begin{array}{l}\text { Hastings Natural } \\
\text { History Reservation, } \\
\text { California }\end{array}$ & $2 \times 3 \mathrm{~km}$ & $\begin{array}{l}Q . \text { agrifolia } \\
Q . \text { douglasii } \\
Q . \text { lobata } \\
Q . \text { chrysolepis } \\
Q . \text { kelloggii }\end{array}$ & $\begin{array}{l}\text { timed counts on } \\
\text { individual trees }\end{array}$ & $\begin{array}{l}21-88 \text { trees per } \\
\text { species }\end{array}$ & 1980-1999 \\
\hline $\begin{array}{l}\text { Jasper Ridge Biological } \\
\text { Station, California }\end{array}$ & $2 \times 2 \mathrm{~km}$ & $\begin{array}{l}Q . \text { agrifolia } \\
Q . \text { douglasii } \\
Q . \text { lobata }\end{array}$ & $\begin{array}{l}\text { timed counts on } \\
\text { individual trees }\end{array}$ & $\begin{array}{l}28-33 \text { trees per } \\
\text { species }\end{array}$ & 1989-1999 \\
\hline Pozo, California & $2 \times 2 \mathrm{~km}$ & $\begin{array}{l}\text { Q. agrifolia } \\
\text { Q. douglasii } \\
\text { O. } \text {.obata }\end{array}$ & $\begin{array}{l}\text { timed counts on } \\
\text { individual trees }\end{array}$ & $\begin{array}{l}25 \text { trees per } \\
\text { species }\end{array}$ & 1989-1999 \\
\hline $\begin{array}{l}\text { Shannon, Reynolds } \\
\text { and Carter } \\
\text { counties, Missouri }\end{array}$ & $15 \times 15 \mathrm{~km}$ & $\begin{array}{l}\text { Q. rubra } \\
\text { Q. coccinea } \\
\text { Q. velutina } \\
\text { Q. alba }\end{array}$ & $\begin{array}{l}\text { means of counts of } \\
\text { traps ( } 20 \text { traps per } 0.1 \\
\text { ha plot) }\end{array}$ & 77 plots & $\begin{array}{l}1993-1995, \\
1997-1999\end{array}$ \\
\hline $\begin{array}{l}\text { Quabbin Resevoir, } \\
\text { Massachusetts }\end{array}$ & $25 \times 20 \mathrm{~km}$ & Q. rubra & $\begin{array}{l}\text { means of counts of } \\
\text { traps ( } 40 \text { traps per } 1 \\
\text { ha plot) }\end{array}$ & 24 plots & 1989-1995 \\
\hline
\end{tabular}




\section{Interspecific dilution of masting}

The population level coefficient of variation, $\mathrm{CV}_{\mathrm{p}}$, was calculated as the ratio of the standard deviation to the mean of yearly average seed production among individuals in a population. When yearly fluctuations in seed production occur randomly we would expect a $\mathrm{CV}_{\mathrm{p}}$ of 1 , but for species that exhibit "true" mast seeding, $\mathrm{CV}_{\mathrm{p}}$ will be higher, potentially exceeding 2 in extreme cases (Kelly 1994). In order to study how variation among sympatric oak species might dampen the overall pulsed nature of masting, we compared intraspecific $\mathrm{CV}_{\mathrm{p}}$ with the $\mathrm{CV}_{\mathrm{p}}$ for all species combined within a community.

\section{Spatial synchrony}

Spatial synchrony among sample locations was quantified using the spatial covariance function, which describes the correlation between time series at pairs of locations as a function of the geographical distance separating samples (Bjørnstad et al. 1999a, Koenig 1999, Buonaccorsi et al. 2001). As described above, samples consisted of yearly counts for individual trees at the California sites and means among traps (located in the same plot) for the Missouri and Massachusetts sites (Table 1). We used a recently developed method, the non-parametric covariance function $(\mathrm{NCF})$, to estimate the spatial covariance function from the acorn count data (Bjørnstad et al. 1999a, b). The NCF uses a smoothing spline to produce direct, continuous estimates of the spatial covariance as a function of lag distance. Confidence intervals for the estimated functions were calculated using bootstrap resampling (500 replicates; Bjørnstad and Falck 2001).

The estimated spatial covariance functions are likely to be biased at the longest lag distances due to the selective location of subpopulations at the periphery of the sample area (Isaaks and Srivastava 1989). To prevent this problem, we limited the maximum distance of the spatial covariance function to $75 \%$ of the shorter geographical dimension (north-south or east-west) for the relatively small California study areas. Geographical dimensions of the Missouri and Massachusetts sites were approximately $20 \mathrm{~km}$, and thus we limited distances to $<10 \mathrm{~km}$ in these areas (Table 1). Overall intraspecific and interspecific synchrony was measured by the mean cross-correlations among all individuals or samples (Bjørnstad and Falck 2001).

\section{Among individual variation in endogenous dynamics}

Masting in oaks may be at least partially explained by a resource depletion phenomenon resulting in negative autocorrelation in seed production among successive years (Sork et al. 1993, Koenig et al. 1994b, Koenig and Knops 2000). We quantified the strength of the variation in endogenous dynamics among individual trees using the 1-yr lag autocorrelation function, $\mathrm{ACF}_{1}$, calculated as:

$\mathrm{ACF}_{1}=\operatorname{cov}\left(\mathrm{N}_{\mathrm{t}} \mathrm{N}_{\mathrm{t}-1}\right) / \operatorname{var}\left(\mathrm{N}_{\mathrm{t}}\right)$

Here we were interested in the variation in masting behavior among trees. Therefore, we calculated values of $\mathrm{ACF}_{1}$ for each tree or plot average for the data-sets shown in Table 1. Values were not calculated for oaks requiring two years to mature acorns ("two-yr" oaks) because of the more complex nature of their lag correlations (Koenig and Knops 2000).

We quantified the extent to which temporal autocorrelation varied in a spatially non-random manner by applying spatial statistics to individual $\mathrm{ACF}_{1}$ values for each tree. The presence of any spatial pattern (nonrandomness, autocorrelation) in $\mathrm{ACF}_{1}$ values was assessed by calculating the spatial correlogram (Isaaks and Srivastava 1989), which estimates the mean autocorrelation between paired values as a function of the lag distance separating pairs of points. Spatial correlograms were estimated using a spline correlogram procedure (Bjørnstad and Falck 2001) to estimate spatial correlation for a series of lag distance values; $95 \%$ confidence intervals for the spatial correlation estimates were calculated using 500 bootstrap replicates.

\section{Results}

Examples of acorn time series from each geographic area are shown in Fig. 1. The California data, as illustrated by the $Q$. douglasii time series from the Hastings Reserve (Fig. 1b), were characterized by what appeared to be an approximate 2-yr cycle in which high acorn crops were followed by low values, a result also revealed by the negative $\mathrm{ACF}_{1}$ values (Table 5). The Missouri and Massachusetts series were shorter and it was therefore more difficult to observe any comparable oscillatory behavior at these sites however the Massachusetts time series (Fig. 1e) clearly did not exhibit the same pattern of alternating high/low crops.

\section{Interspecific dilution of masting}

With the exception of $Q$. velutina in Missouri, values of $\mathrm{CV}_{\mathrm{p}}$, for individual species were greater than those for all species at a site combined (Table 2). This indicates that total mast production at a site was generally more uniform through time than was mast production for individual species within a community. 

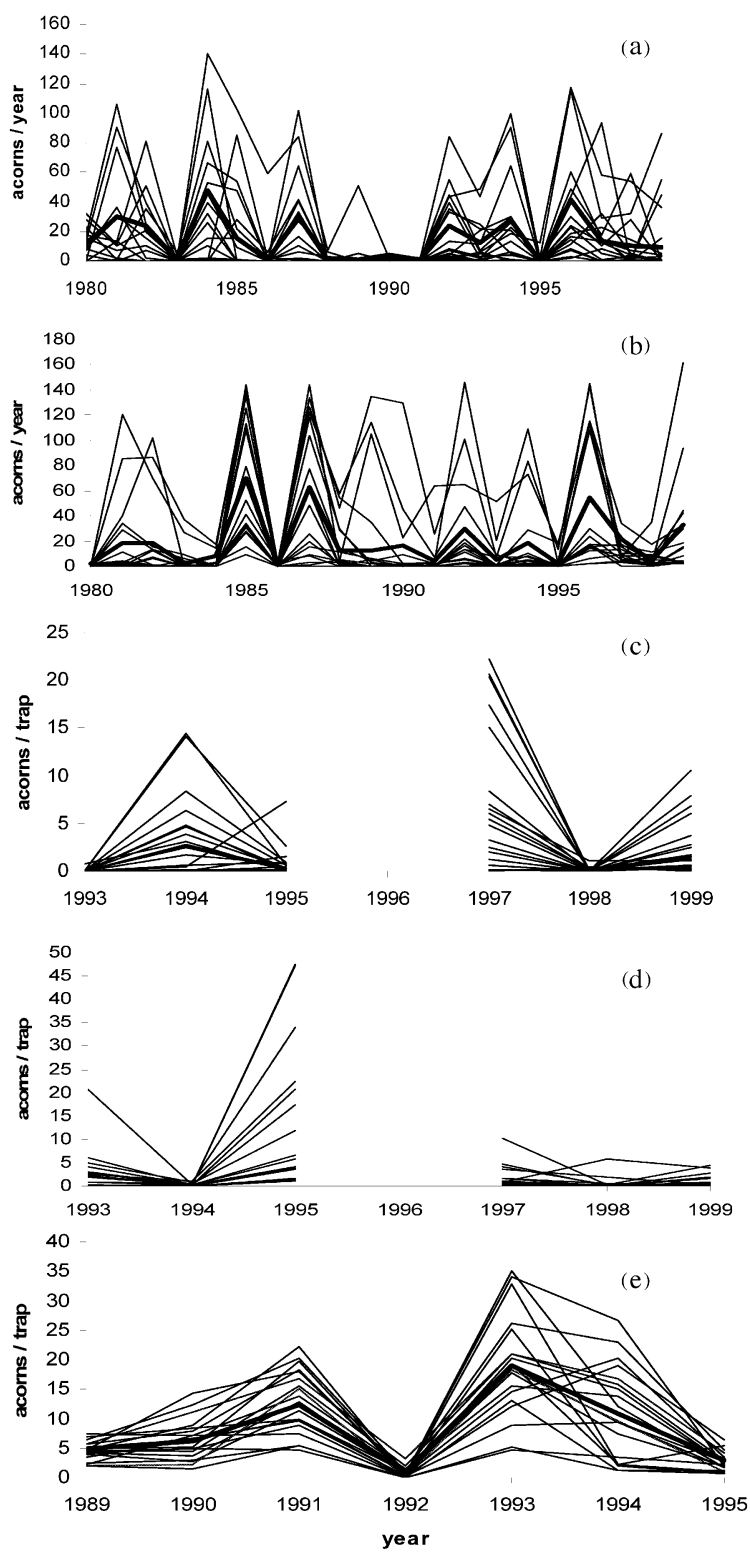

Fig. 1. Example time series of mast production. (a) Hastings Reservation (California) site, Q. agrifolia, (b) Hastings Reservation, $Q$. douglasii, (c) Missouri, $Q$. coccinea, (d) Missouri, $Q$. alba, (e) Massachusetts, Q. rubra. In (a-b) each line represents values for individual trees; in (c-e), lines represent yearly means for each plot. Heavy lines represent yearly grand means.

\section{Spatial synchrony}

All of the time series showed some evidence of both intraspecific and interspecific synchrony in seed production. The spatial covariance functions ( $\mathrm{SCFs}$ ) for the California, Missouri, and Massachusetts data are shown in Fig. 2 and 3. While the shape of the SCFs exhibited slight non-linearity, fluctuations did not exceed confidence intervals and were therefore not consid-
Table 2. $\mathrm{CV}_{\mathrm{p}}$ for individual species and for all oaks combined at each study location.

\begin{tabular}{llll}
\hline & & $\mathrm{CV}_{\mathrm{p}}$ & \\
\cline { 3 - 4 } & & $\begin{array}{l}\text { Species } \\
\text { specific }\end{array}$ & $\begin{array}{l}\text { All species } \\
\text { combined }\end{array}$ \\
\hline Hastings & Q. douglasii & 1.03 & 0.68 \\
Reservation, & Q. agrifolia & 0.92 & \\
California & Q. lobata & 0.92 & \\
& Q. kellogii & 1.14 & \\
Jasper & Q. chrysolepis & 0.89 & \\
Ridge, & Q. douglasii & 0.95 & 0.90 \\
California & Q. agrifolia & 0.96 & \\
Pozo, & Q. lobata & 1.15 & \\
California & Q. douglasii & 0.97 & 0.76 \\
& Q. lobrifolia & 0.92 & \\
Missouri & Q. velutina & 0.90 & 0.59 \\
& Q. coccinea & 1.11 & \\
& Q. alba & 1.21 & \\
\hline
\end{tabular}

ered significant. Thus, these data indicate that synchrony did not decline with distance over the geographic scale $(<10 \mathrm{~km})$ examined here.

\section{Interspecific synchrony}

Synchrony between species in mean number of acorns produced each year was often high (Table 3 and 4). At the three California sites, intraspecific synchrony among trees was on the order of 0.5 or higher. At Hastings Reservation, Q. kelloggii and $Q$. chrysolepis, the two species that require two years to mature acorns (2-yr species), were asynchronous with the species requiring a single year to mature acorns (1-yr species). Within the 1-yr species, synchrony between $Q$. douglasii and $Q$. lobata was generally as high as intraspecific levels of synchrony, whereas Q. agrifolia was generally less synchronized with the two other 1-yr oak species. In Missouri, $Q$. alba, a 1 -yr species, was poorly synchronized with both 2 -yr species, $Q$. velutina and $Q$. coccineana, but $Q$. velutina and $Q$. coccineana were highly synchronous with each other (Table 4).

\section{Variation in endogenous dynamics among individuals}

The mean $\mathrm{ACF}_{1}$ for individual trees were always negative (Table 5). The mean $\mathrm{ACF}_{1}$ for $Q$. douglasii and $Q$. lobata were virtually identical, indicating an inherent similarity in their endogenous dynamics. Values for $Q$. agrifolia were significantly greater than the other two California species that mature acorns in a single year.

Spatial correlograms of $\mathrm{ACF}_{1}$ for each of the three species at Hastings Reservation are shown in Fig. 4(ac). All three species exhibited similar patterns of spatial dependence though deviation from spatial randomness 

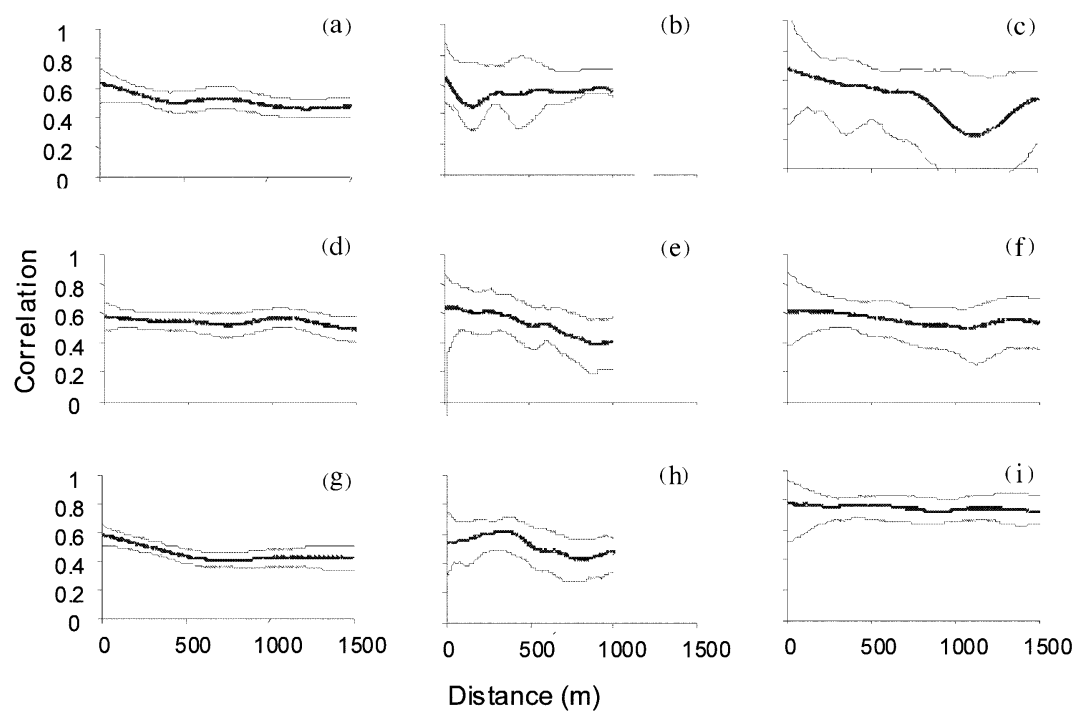

Fig. 2. The spatial covariance functions estimated from acorn count data from California oaks. The thin lines represent the 95\% bootstrap confidence intervals. (a) Q. agrifolia, Hastings Reservation, (b) $Q$. agrifolia, Jasper, (c) $Q$. agrifolia, Pozo, (d) Q. douglasii, Hastings Reservation, (e) $Q$. douglasii, Jasper, (f) Q. douglasii, Pozo, (g) Q. lobata, Hastings Reservation, (h) Q. lobata, Jasper, (i) $Q$. lobata, Pozo. was only significant for $Q$. lobata over distances $0-250$ m. A similar significant pattern of spatial autocorrelation was observed in $Q$. alba in Missouri (Fig. 4d).

\section{Discussion}

There have been several prior investigations of the extent to which mast seeding operates synchronously among geographically disjunct populations (Koenig et al. 1994b, 1999, Koenig and Knops 1998, 2000). These studies indicate that synchrony is greatest among nearby populations and declines to zero as the distance between populations increases; however populations up to $1000 \mathrm{~km}$ apart may exhibit some detectable synchrony. In contrast, the analyses performed here focus on spatial scales considerably smaller than those previously studied. For each of the oak species that we analyzed at each site, we found little evidence that synchrony declined as inter-sample distance varied from $200 \mathrm{~m}$ to $10 \mathrm{~km}$. (Fig. 2, 3).

Two possible (not mutually exclusive) causes for spatially extended synchrony in mast seeding are pollen movement (Isagi et al. 1997, Satake and Iwasa 2002a, b) and synchronous environmental forcing (the Moran (1953) effect; Piovesan and Adams 2001, Koenig 2002). Data on pollen movement in oaks is variable, but several studies have generally confirmed that most polli- (a)

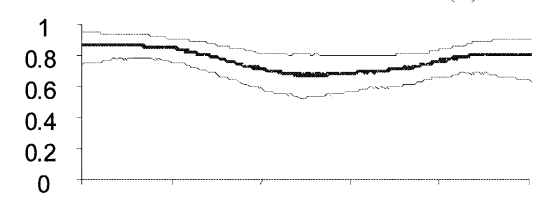

(b)

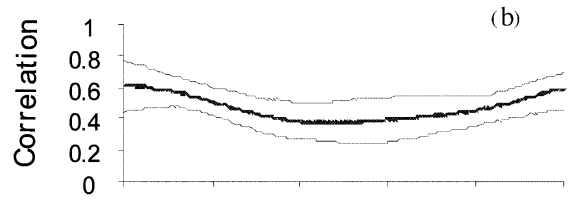

(d)

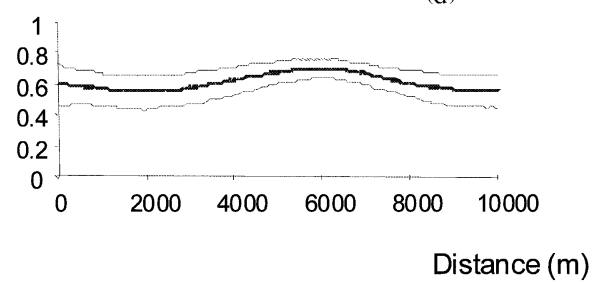

(c)

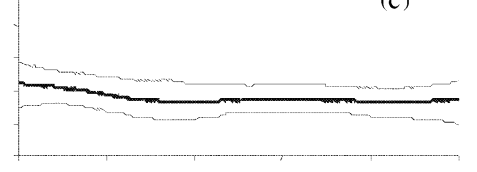

(e)

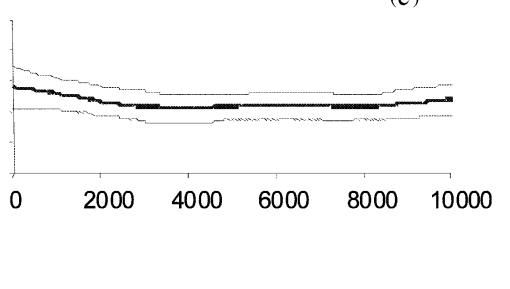

Fig. 3. The spatial covariance functions estimated from acorn production data from the Massachusetts, and Missouri sites. Thin lines represent the $95 \%$ bootstrap confidence intervals. (a) $Q$. rubra, Massachusetts, (b) $Q$ coccinea, Missouri, (c) $Q$. velutina, Missouri, (d) $Q$. alba, Missouri, (e) Total (sum of all species) acorns, Missouri. 


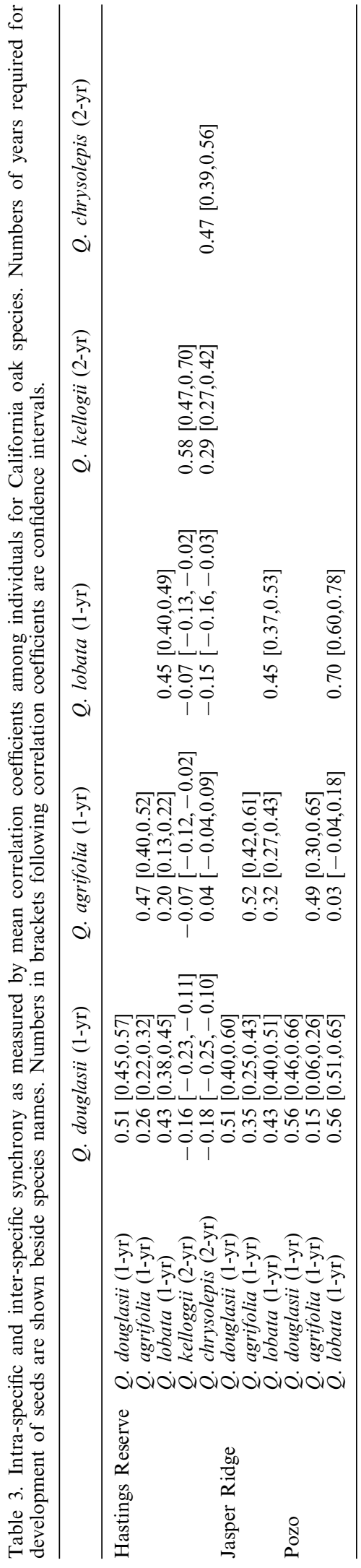

nation between trees is limited to distances $<100 \mathrm{~m}$ apart (Adams 1992, Dow and Ashley 1998, Knapp et al. 2001, Sork et al. 2002). Consequently, it is likely that if pollen dispersal were the primary mechanism, synchronization should be locally high to lag distances $<200-300 \mathrm{~m}$ (Satake and Iwasa 2002a, b), unless internal resource allocation is highly non-linear, in which case even localized pollen coupling can result in 'phase-locking' and region-wide synchronization (Satake and Iwasa 2002a). We note that there is not currently any evidence of such non-linear resource allocation in oaks. In most of the data-sets we observed virtually no decrease in synchrony with distance. We therefore tentatively conclude that the Moran effect is the more likely cause of synchronous masting in these species. In some of the data sets there is, however, a tendency of synchrony to decline slightly with increasing lag distance (Fig. 2, 3), and this pattern may be consistent with patterns of synchrony predicted from the combined action of both pollen-coupling and regional stochasticity (Satake and Iwasa 2002a, b). Future, more mechanistic studies will be needed to resolve the local interaction between intrinsic and extrinsic forces on oak masting.

Koenig and Knops (2000) studied synchrony in masting by trees over much larger scales and found that patterns of synchrony as a function of distance generally matched patterns of synchrony in various weather variables. They therefore concluded that synchrony at these larger scales was due to the Moran effect. At the much smaller spatial scale of our study, weather variables are likely to exhibit a similar pattern of near constant synchrony as a function of distance (Koenig 2002). This correspondence between patterns of synchrony in masting with patterns in weather lends support to the idea that the Moran effect can cause synchrony in mast production also at local scales.

The mean level of intraspecific synchrony in each of the California oak species was relatively consistent among all species at all three sites. Interspecific synchrony among $Q$. douglasii and $Q$. lobata was generally as high as intraspecific synchrony. The 2-yr species $(Q$. kelloggii and $Q$. chrysolepis) were asynchronous with the 1-yr species. At the Missouri site, the 1-yr Q. alba was relatively asynchronous with the $2-\mathrm{yr} Q$. velutina and $Q$. coccineana. These findings of greater interspecific synchrony between species that require the same number of years to produce seed than between species requiring different numbers of years to produce seeds is in agreement with similar findings by Koenig and Haydock (2001) who analyzed a more limited data-set.

The most likely explanation for this pattern is that species that share a similar process of endogenous dynamics, as represented most critically by the number of years they require to mature acorns, are more likely to be synchronized by simultaneous weather effects 
Table 4. Intra-specific and inter-specific synchrony as measured by mean correlation coefficients among individuals for Missouri oak species. Numbers of years required for development of seeds are shown beside species names. Numbers in brackets following correlation coefficients are confidence intervals.

\begin{tabular}{llcc}
\hline & Q. velutina $(2-\mathrm{yr})$ & Q. coccinea $(2-\mathrm{yr})$ & Q. alba $(1-\mathrm{yr})$ \\
\hline Q. velutina $(2-\mathrm{yr})$ & $0.36[0.30,0.44]$ & & \\
Q. coccinea $(2-\mathrm{yr})$ & $0.30[0.23,0.35]$ & $0.50[0.42,0.59]$ & \\
Q. alba $(1-\mathrm{yr})$ & $0.20[0.16,0.31]$ & $-0.04[-0.16,0.00]$ & $0.53[0.44,0.61]$ \\
\hline
\end{tabular}

Table 5. Mean (standard error of the mean shown in parenthesis) number of acorns per sample and 1-yr lag autocorrelation function $\left(\mathrm{ACF}_{1}\right)$.

\begin{tabular}{llll}
\hline Location & Species & Mean & $\mathrm{ACF}_{1}$ \\
\hline Hastings & Q. douglasii & $19.6(2.4)$ & $-0.211(0.022)$ \\
Reservation & Q. agrifolia & $15.8(1.8)$ & $-0.142(0.023)$ \\
\multirow{2}{*}{ Missouri } & Q. lobata & $20.8(1.9)$ & $-0.211(0.021)$ \\
& Q. alba & $37.2(4.8)$ & $-0.231(0.030)$ \\
\hline
\end{tabular}

than those with very different dynamics; the differences in dynamics of 1-yr vs 2-yr species was previously reported by Sork et al. (1993) and Koenig and Knops (2000). Such differences in endogenous dynamics violate one of the assumptions to Moran's (1953) theorem, namely that geographically disjunct populations do not differ in their endogenous dynamics. The relaxation of this assumption in the systems studied here may result in decreased spatial synchrony in seed production. Peltonen et al. (2002) studied spatial synchrony in forest insect populations and used linear simulation models to demonstrate that geographical variation in endogenous dynamics caused a dilution of the synchronizing effect of weather. A similar mechanism is likely to be responsible for the low synchrony between 1-yr and 2-yr oak species.
The $\mathrm{ACF}_{1}$ values at the California and Missouri sites tended to be spatially autocorrelated at distances of 250 $\mathrm{m}$ or less (Fig. 4), suggesting non-random intraspecific variation in endogenous dynamics. This intraspecific variation in endogenous dynamics was also closely related to the mean seed yield per individual (Table 5). In general, the dynamics of the 1-yr oak species appear to be well represented by the first-order auto-regressive model:

$\mathrm{N}_{\mathrm{t}}=\mathrm{a}+\mathrm{bN}_{\mathrm{t}-1}+\varepsilon_{\mathrm{t}}$

If we substitute the population mean, $\mu$, for $\mathrm{N}_{t}$ and $\mathrm{N}_{\mathrm{t}-1}$ we get:

$\mu,=a+b \mu$

which can be expressed as:

$\mathrm{b}=1-\mathrm{a} / \mu$

Thus, if we assume a constant intercept, a, we would expect the slope, $b$, to be inversely related to the mean, thus explaining the negative associations between the mean and the $\mathrm{ACF}_{1}$ in Table 5. A biological explanation for this phenomenon is that those tree species or
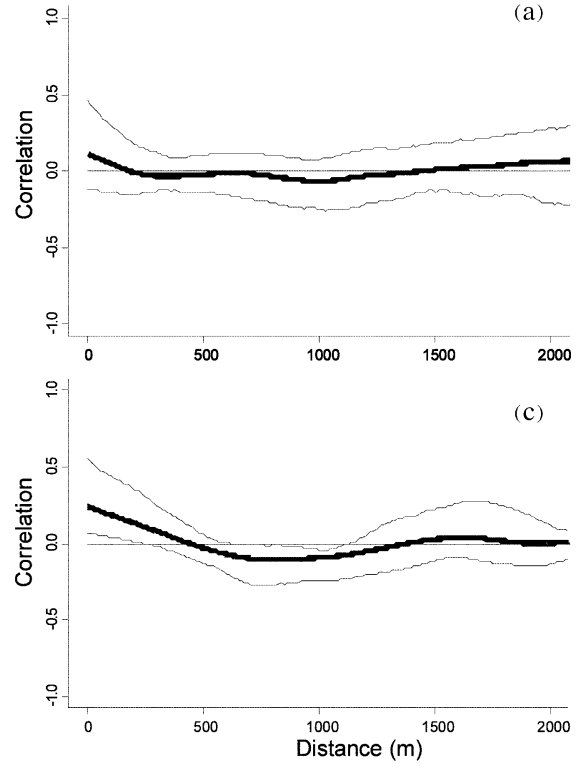

(c)

\section{웅}

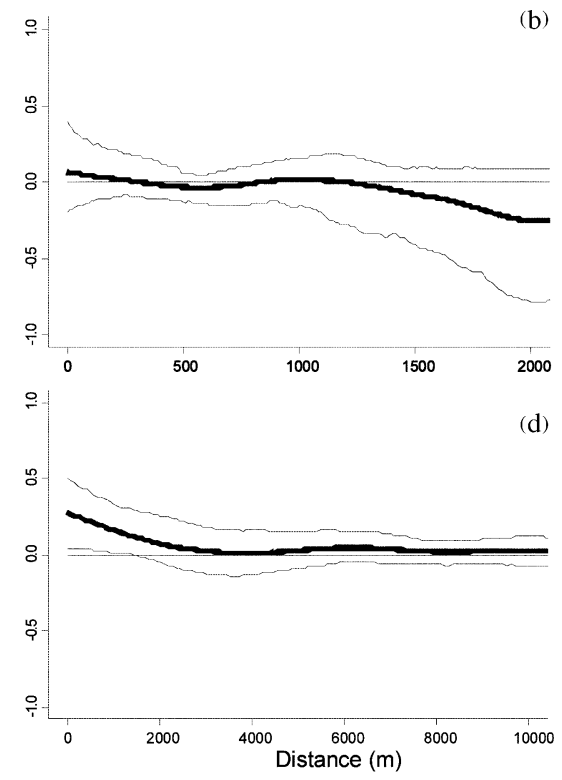

(b)
Fig. 4. Spatial correlograms of 1-yr lag autocorrelation function $\left(\mathrm{ACF}_{1}\right)$ values from individual tree time series. Heavy lines are spline correlograms and light lines are $95 \%$ confidence intervals estimated from 500 bootstrap replicates (Bjørnstad and Falck 2001). (a) Q. agrifolia, Hastings Reservation (California) site, (b) $Q$. douglasii Hastings Reservation (California) site, (c) Q. lobata, Hastings Reservation (California) site, (d) $Q$. alba at the Missouri site. 
individual trees with high seed production are also the species or individuals showing the most extreme variability (measured by $\mathrm{ACF}_{1}$ ) in seed production. Species or individual trees with low seed production tend to exhibit less serial autocorrelation, and consequently fluctuate in a more random fashion.

The finding of spatial autocorrelation in $\mathrm{ACF}_{1}$ values (Fig. 4c, d) suggests that endogenous mast dynamics in individual trees may be related to some autocorrelated feature of the habitat. We obtained topographical data for the Hastings Reservation and Missouri sites and preliminary exploration of these data indicated associations between individual $\mathrm{ACF}_{1}$ values and aspect. However results from the Hastings Reservation and Missouri were opposite: in California, oaks on southfacing slopes produced the most seed and exhibited the strongest negative serial correlation, whereas in Missouri, oaks on the north-facing slopes produced the most seeds and were most strongly negatively autocorrelated.

The reasons for these different habitat relationships in Missouri and California are not clear. There is considerable evidence that temporal variation in seed production is closely tied to resource availability in plants (Sork et al. 1993, Kelly 1994, Rees et al. 2002). However, within stand variation in mast production and resource availability is less consistent; there is considerable variation among species and/or regions in the relationship between tree vigor and mean seed production. Some studies indicate that fast growing, dominant trees with large crowns produce more seed over their life-time (Goodrum et al. 1971, Wolgast and Stout 1977, Healy et al. 1999) but studies of other species have found that oaks of low vigor, growing on the worst sites produce the most seeds (Gysel 1957). This inconsistent relationship between tree vigor and seed production may be at the root of the differing habitat relationships found in California and Missouri oaks.

Even though the relationships may differ among species and the precise mechanisms are not understood, both study areas did exhibit some intraspecific spatial variation in the temporal autocorrelation in mast production. This variation probably reflects intraspecific variation in the extent to which resources are depleted by mast events. This variation probably dampens the synchronizing effect of weather (Moran effect) on mast synchrony within stands. In addition to intraspecific variation in endogenous dynamics in seed production, interspecific variation also appears to reduce synchrony in total mast production (Table 3, 4). However, despite these desynchronizing effects, spatial synchrony in masting is still pronounced and is likely to play an important role in synchronizing populations of seed consumers and indirectly affect synchrony at higher trophic levels (Kelly 1994, Liebhold et al. 2000, Ostfeld and Keesing 2000).
Acknowledgements - This work was conducted as part of the "Evolutionary causes and ecological consequences of mast seeding in plants" working group supported by the National Center for Ecological Analysis and Synthesis, a Center funded by NSF (Grant \# DEB-0072909), the University of California, and the Santa Barbara campus. M.P. was funded by a postdoctoral grant from the Academy of Finland. We thank Pedro Jordano for useful comments on an earlier draft.

\section{References}

Adams, W. T. 1992. Gene dispersal within forest tree populations. - New Forests 6: 217-220.

Bjørnstad, O. N. and Falck, W. 2001. Spatial covariance functions: estimation and testing. - Envir. Ecol. Stat. 8: 53-70.

Bjørnstad, O. N., Ims, R. A. and Lambin, X. 1999a. Spatial population dynamics: analyzing patterns and processes of population synchrony. - Trends Ecol. Evol. 14: 427-432.

Bjørnstad, O. N., Stenseth, N. C. and Saitoh, T. 1999b. Synchrony and scaling in dynamics of voles and mice in northern Japan. - Ecology 80: 622-637.

Buonaccorsi, J. P., Elkinton, J. S., Evans, S. R. et al. 2001. Measuring and testing for spatial synchrony. - Ecology 82 : $1668-1679$

Buonaccorsi, J. P., Elkinton, J., Koenig, W. et al. 2003. Measuring masting behavior: relationships among population variation, individual variation and synchrony. - J. Theor. Biol. (in press).

Dow, B. D. and Ashley, M. V. 1998. High levels of gene flow in bur oak revealed by paternity analysis using microsatellites. - J. Heredity 89: 62-70.

Elkinton, J. S., Healy, W. M., Buonaccorsi, J. P. et al. 1996. Interactions among gypsy moths, white-footed mice, and acorns. - Ecology 77: 2332-2342.

Goodrum, P. D., Reid, V. H. and Boyd, C. E. 1971. Acorn yields, characteristics, and management criteria of oaks for wildlife. - J. Wildl. Manage. 35: 520-532.

Gysel, L. W. 1957. Acorn production on good, medium, and poor oak sites in southern Michigan. - J. Forest. 55: $570-574$.

Healy, W. M., Lewis, A. M. and Boose, E. F. 1999. Variation of red oak acorn production. - Forest Ecol. Manage. 1116: $1-11$.

Herrera, C. M. 1998. Population-level estimates of interannual variability in seed production: what do they actually tell us? - Oikos 82: 612-616.

Herrera, C. M., Jordano, P., Guitián, J. et al. 1998. Annual variability in seed production by woody plants and the masting concept: reassessment of principles and relationship to pollination and seed dispersal. - Am. Nat. 152: $576-594$.

Isaaks, E. H. and Srivastava, R. M. 1989. An introduction to applied geostatistics. - Oxford Univ. Press.

Isagi, Y., Sugimura, K., Sumida, A. et al. 1997. How does masting happen and synchronise. - J. Theor. Biol. 187: $231-239$.

Janzen, D. H. 1969. Seed-eaters versus seed size, number, toxicity and dispersal. - Evolution 23: 1-27.

Kelly, D. 1994. The evolutionary ecology of mast seeding. - Trends Ecol. Evol. 9: 465-470.

Kelly, D. and Sork, V. L. 2002. Mast seeding in perennial plants: why, how, where? - Annu. Rev. Ecol. Syst. 33: 427-447.

Knapp, E. E., Goedde, M. A. and Rice, K. J. 2001. Pollenlimited reproduction in blue oak: implications for wind pollination in fragmented populations. - Oecologia 128: $48-55$.

Koenig, W. D. 1999. Spatial autocorrelation of ecological phenomena. - Trends Ecol. Evol. 14: 22-26. 
Koenig, W. D. 2002. Global patterns of environmental synchrony and the Moran effect. - Ecography 25: 283-288.

Koenig, W. D. and Haydock, J. 2001. Oaks, acorns, and the geographical ecology of acorn woodpeckers. - J. Biogeogr. 26: $159-165$.

Koenig, W. D. and Knops, J. M. H. 1998. Scale of mast-seeding and tree-ring growth. - Nature 396: 225-226.

Koenig, W. D. and Knops, J. M. H. 2000. Patterns of annual seed production by northern hemisphere trees: a global perspective. - Am. Nat. 155: 59-69.

Koenig, W. D. and Knops, J. M. H. 2001. Seed-crop size and eruptions of North American boreal seed-eating birds. - J. Anim. Ecol. 70: 609-620.

Koenig, W. D., Knops, J. M. H., Carmen, W. J. et al. 1994a Estimating acorn crops using visual surveys. - Can. J. For. Res. 24: 2105-2112.

Koenig, W. D., Mumme, R. L., Carmen, W. J. et al. 1994b. Acorn production by oaks in central coastal California: variation within and among years. - Ecology 75: 99109.

Koenig, W. D., Knops, J. M. H., Carmen, W. J. et al. 1999 Spatial dynamics in the absence of dispersal: acorn production by oaks in central coastal California. - Ecography 22 499-506.

Koenig, W. D., Kelly, D., Sork, V. L. et al. 2003. Dissecting components of population-level variation in seed production and the evolution of masting behavior. - Oikos 102: $581-591$.

Liebhold, A., Elkinton, J., Williams, D. et al. 2000. What causes outbreaks of the gypsy moth in North America? - Pop. Ecol. 42: 257-266.

Moran, P. A. P. 1953. The statistical analysis of the Canadian lynx cycle. II Synchronization and meteorology. - Aust. J. Zool. 1: 291-298.

Ostfeld, R. S. and Keesing, F. 2000. Pulsed resources and community dynamics of consumers in terrestrial ecosystems. - Trends. Ecol. Evol. 15 (6): 232-237.

Peltonen, M., Liebhold, A. M., Bjørnstad, O. N. et al. 2002. Spatial synchrony in forest insect outbreaks: roles of re- gional stochsaticity and dispersal. - Ecology 83: 31203129 .

Piovesan, G. and Adams, J. M. 2001. Masting behaiour in beech: linking reproduction and climatic variation. - Can. J. Bot. 79: 1039-1047.

Rees, M., Kelly, D. and Bjørnstad, O.N. 2002. Snow tussocks, chaos and the evolution of mast seeding. - Am. Nat. 160: 44-59.

Satake, A. and Iwasa, Y. 2002a. Spatially limited pollen exchange and a long-range synchronization of trees. - Ecology 83: 993-1005.

Satake, A. and Iwasa, Y. 2002b. The synchronized and intermittent reprduction of forest trees ins mediated by the Moran effect, only in association with pollen coupling. - J. Ecol. 90: 830-838.

Selås, V., Hogstad, O. and Andersson, G. 2001. Population cycles of autumnal moth, Epirrita autumnata, in relation to birch mast seeding. - Oecologia 129: 213-219.

Silverton, J.W. 1980. The evolutionary ecology of mast seeding in trees. - Biol. J. Linn. Soc. 14: 235-250.

Sork, V. L. 1993. Evolutionary ecology of mast-seeding in temperate and tropical oaks (Quercus spp.). - Vegetatio 107/108: 133-147.

Sork, V. L., Stacey, P. and Averett, J. E. 1983. Utilization of red oak acorns in non-bumper crop year. - Oecologia 59: $49-53$.

Sork, V. L., Bramble, J. and Sexton, O. 1993. Ecology of mast-fruiting in three species of North American deciduous oaks. - Ecology 74: 528-541.

Sork, V. L., Davis, F. W., Smouse, P. E. et al. 2002. Pollen movement in declining populations of California Valley oak: where have all the fathers gone? - Mol. Ecol. 11: $1657-1668$

Sullivan, N. H. 2001. An algorithm for a landscape level model of mast production. PhD thesis. Univ. of Missouri - Columbia, USA.

Wolgast, L. J. and Stout, B. B. 1977. Effects of age, stand density, and fertilizer application on bear oak reproduction. - J. Wildl. Mange. 41: 685-691. 